\title{
The Experience of Borders: Montenegrin Tribesmen at War
}

\author{
URSULA REBER
}

In Austrian imaginings of the Balkans as a pastoral wilderness defended by cunning warlords loyal to their tribes alone, Montenegro figured as especially archetypal. Although the diminutive principality never posed a threat to Austria-Hungary's armed forces or the multinational Empire per se, it rose to prominence in its German-speaking press ${ }^{1}$ as well as through travelogues and military reports. ${ }^{2}$ While the military emphasized that Montenegrins were always battle-ready and cunning in their strategies, the image promoted by Austrian papers was ambiguous: The heroic chivalry of the otherwise untrustworthy Montenegrins culminated in blood feuds over stolen sheep. The notion that they were modern relics of ancient Sparta, supported in Britain by Prime

1 Especially the Neue Freie Presse (Vienna).

2 Josef Schön, Montenegrinische Kriegführung und Taktik, mit 1 Skizzentafel (Vienna: Seidel \& Sohn k.u.k. Hofbuchhändler, 1909), (essay originally appeared in Organ der militär-wissenschaftlichen Vereine, vol. 1, 1898, by Hauptmann Josef Schön des Generalstabskorps [later Kommandant des Infanterieregiments Erzherzog Carl Nr. 3]); Eduard Rüffler, Eine strategische Studie über Dalmatien, Montenegro, Bosnien und die Hercegovina mit einer Karte des Insurrections-Schauplatzes (Prague: H. Carl J. Satow, 1870); H. A., Die türkische Wehrmacht und die Armeen der Balkanstaaten: Bulgarien, Griechenland, Rumänien, Serbien und Montenegro (Vienna: Verlags-Anstalt "Reichswehr," 1892); Anon., Die serbische und montenegrinische Armee, mit Textskizzen u. Abb. (Vienna: Josef Roller \& Co., 1912); Spiridon Gopčević, Der Krieg Montenegro's gegen die Pforte im Jahr 1876, mit einer Kartenbeilage, Schlachtpläne enthaltend (Vienna: J. W. Seidel \& Sohn, 1877); J. J. Šestak and F. v. Scherb, Des Paschalik's Hercegovina und des Fürstenthums Crnagora sammt Karte (Vienna: self-published, 1862); for a more thorough analysis of the military treatises, see also Ursula Reber, Habsburgische Begegnungen mit nomadischen Kriegerstämmen: Montenegro als strategischer Schauplatz, http://www.kakanien. ac.at/beitr/fallstudie/UReber4.pdf (accessed January 13, 2010). 
Minister William Ewart Gladstone (1868-1874), was popular in Germany as well. ${ }^{3}$ Imported to Austria, high-flown praise for the "noble savage" merged with the image of the wild Montenegrin (or Albanian or Serbian) tribal warrior to create an, if not universal, at least enduring, interest in Montenegrin fighting techniques and their social and cultural bases.

This chapter will outline the construction of the prevailing discourse of the Montenegrin fighter, his partisan tactics, and his quasi-nomadic society as perceived by Austrian officers. Travelogues, ethnographic and geomorphologic treatises, and military studies of Austrian origin were all contributors, but his gestalt is not solely the product of Austro-Hungarian discourse, notable for its lack of continuity. Authors repeatedly emphasize their scientific intentions, but their imagery is of popular origin. As the occasion demanded, Austrian authorities, familiar with received notions of Montenegro's wild lands and men, took part in the discourse or exploited its suggestive power.

It can be difficult to place the protagonists of the popular and proto-ethnographic discourse under analysis here; most often, they are third-tier military men, adventurers, or amateur scholars, and it should be assumed that their part in the making of a discourse with claims to authority lies somewhere between shaping it and the transposition of extant opinions to the specific contexts of the pan-Balkan cultural-tribal threat and the resultant need for AustriaHungary's civilizing mission. This uncertainty regarding agency-whether it was the entire discourse or rather individual agents with their respective interests who created the situation of political instability-encouraged a paranoid atmosphere in which an entire set of "scientific" tools was wielded to reconnoiter a strange territory, people, and culture anew. This undertaking produced knowledge of the foreigners and allowed the development of strategies for successful interaction. At the same time, its central genre continued to be a combination of travelogue, diary, and geopolitical/-cultural treatise, ${ }^{4}$ structured along categorical lines to underline its scientific worth. ${ }^{5}$

The chapter addresses Austrian fantasies of war and territorial gain as well as the elusive frontier, sketching the geopolitical conflict that led to the Balkan

3 For Germany, see, for example, Gustav Hertzberg, Montenegro und sein Freiheitskampf:Vortragvon Dr. Gustav Hertzberg (Halle:Schrödel\&Simon, 1853). Generally, German travelogues lack the ambivalence toward Montenegro's culture found in most Austrian writings.

4 Zoran Konstantinović, Deutsche Reisebeschreibungen über Serbien und Montenegro (Munich: Oldenbourg, 1960), 111-137.

5 It is evident that this does not work out as intended. Texts on which those treatises relied were tendentious themselves. See, for example, Gopčevič as hypotext for many Austrian military treatises. See Reber, "Habsburgische Begegnungen"; on Gopčevič, see also Konstantinović, Deutsche Reisebeschreibungen, 119-123. 
military conflicts and diplomatic crises ${ }^{6}$ without focusing on particular events or military history. While it is not clear whether Austria actually had territorial interests in Montenegro, it reacted to Montenegro's claims to Albanian and Herzegovinian territory with at least the pretence of interest. With active economic and territorial interests elsewhere in the Balkans, Austria-Hungary had long been afraid that Montenegro and Serbia might join forces against its protectorate in Herzegovina to enforce territorial claims or simply to drive out the foreign religious and cultural influence. ${ }^{7}$ Austro-Hungarian distrust was primarily directed against Serbia, but tiny Montenegro, with its aspirations toward autonomy, played a considerable role in the construction of Serbia as an enemy. Since both peoples claimed common Serbian roots, Austro-Hungarian representatives had to reckon with the possibility of a united Serbia-Montenegro. I will discuss the imagined link between Montenegro's rugged geography and its political status, especially the instability of its borders and the tiresome process of redrawing them in the wake of the Congress of Berlin. The constant clash of "natural" borders with proposed political borders, and the impediments posed by war, offer the opportunity to explore differing conceptions of border constructs. Finally, I will look at the importance of popular "ethnographic" discourse for the military, especially the Austrian military government of Montenegro from 1916 onward and its justification of collective punishments.

\section{Montenegrin Warlords}

Praise for Montenegrins' historical bravery, their successful struggle against the Ottoman Empire, and their love of freedom is still in circulation, whether in Montenegrin self-representations or in scholarly publications, such as

6 John D. Treadway, The Falcon and the Eagle: Montenegro and Austria-Hungary, 1908-1914 (West Lafayette, IN: Purdue, 1983).

7 Cf. Feldmarschall Conrad, Aus meiner Dienstzeit 1906-1918, 3 vols. (Vienna: Rikola, 1921-1922).

8 Ethnography and ethnographic knowledge are used throughout this chapter in a nondisciplinary sense. The definitions of geography, society, and culture, as they have been drawn by travelers-military and nonmilitary-do not represent a scientific concept in this sense. They are not meant to establish an ethnographic discipline. Nevertheless, using geography as their main point of reference, they come close to an anthropogeography (Friedrich Ratzel) avant la lettre. In establishing a specific transcendence of the archaic mountaineous warrior tribal legacy based on the value of honor, one could also speak of the establishment of a Balkan/Montenegrin geo-aesthetics (this term is borrowed from the Marc Ries, Geoästhetik der Medien [unpubl.]) as practices of the perception of space as channeled and transformed by media and discourses. 
Elizabeth Roberts's recent historical study. ${ }^{9}$ It becomes difficult to disentangle the self-image conveyed by Montenegrin accounts from those ascribed to them, particularly in the many comparisons to ancient Spartans and the early Swiss.

In current usage, the loaded term "warlord" refers exclusively to self-appointed military leaders who consistently violate human rights. I employ it for its broad allusion to those who committed both legally sanctioned and prelegal, if not illegal-from the vantage point of modern states based on the separation of powers - acts of war which they "justified" by reference to social values, such as honor and vengeance as well as resistance and self-defense. In the Montenegrin case, the term implied an equal readiness to repel foreign invaders and to abduct neighbors' sheep. The myth-building efficacy of a nation of warrior heroes, prepared to confront any territorial threat, arises in response to desires both internal and external: to invoke a national history, to establish a lasting collective memory, to position both history and memory between ancient patriarchal and modern resistance-driven narratives, and to mark those narratives as worthy for inclusion in a shared history of Europe. These narrative features were already on the verge of acquiring the status of myth in the nineteenth and early twentieth centuries. ${ }^{10}$ But even then, a state ruled by warlords was not considered economically viable, and current Montenegrin independence, to a certain extent, reprises the "dependent independence" that followed the Congress of Berlin of 1878.

E. V. Zenker, a member of the Austrian State Council who reported on Montenegro's economy using material collected in 1908 and 1909, stated circa 1917 that "an independent Montenegro will hardly attain economic autonomy under its own power, and for that reason it has no natural claim to political independence." ${ }^{11}$ The reasoning behind the dismissal of Montenegro's politi-

9 Elizabeth Roberts, Realm of the Black Mountain: A History of Montenegro (Ithaca, NY: Cornell University Press, 2007).

10 Anthropologists claim that there is more to heroism than pure myth and selfrepresentation. Gerhard Gesemann, for example, critically discusses the sociological, group-related fact of the "heroic lifestyle" in Montenegro. Apart from his creating close relations between the landscape and a people's mentality [Volkscharakter], his argument that the "agon" society is reflected in many oral literary genres is convincing. See Gerhard Gesemann, Der montenegrinische Mensch: Zur Literaturgeschichte und Charakterologie der Patriarchalität (Prague: Kommissionsverlag der J. G. Calveschen Universitäts-Buchhandlung, 1934).

11 Montenegro: Eine Denkschrift über die wirtschaftliche Erschließung des Landes auf Grund einer im Auftrage des k.u.k. Kriegsarchivs unternommenen Studienreise verfasst vom Reichsrats-Abgeordneten E. V. Zenker k.u.k. Fähnrich (Vienna: 1919), 20: "Ein selbständiges Montenegro wird kaum jemals aus eigener Kraft sich zur wirtschaftlichen Unabhängigkeit erheben, und eben deshalb hat es keinen natürlichen Anspruch auf selbständige Staatlichkeit." 
cal autonomy is based less on its barren soil than on its inhabitants' lifestyle: With their disdain for industry and trade, patriarchal warriors were regarded as lazy. ${ }^{12}$ From the start, Zenker draws a connection between Montenegro's economic insufficiency and its social and cultural backwardness, which he pointedly calls "primitivism." ${ }^{13}$ In the discourse of enlightenment and progress, "primitivism" obstructed the development of a middle class and of commerce generally. The situation was exacerbated by Montenegro's social structure, restricted to bonds of family, clan, and comrades-in-arms. By inhibiting broader group loyalties, these ties prevented even the one honorable male profession-soldiering-from aspiring to professionalism. The country's "primitive" social structure extended to its army, where tactics and the arrangement of troops played only minor roles as opposed to the abilities of the individual fighter. In the critical view of Austrian strategists, the Montenegrin army lacked both discipline and strategy, ${ }^{14}$ and its tactics were the hit-and-run methods of partisans.

But the "primitive" was not always pejorative, even in the military context. Many ethnographers used the term in a rather positive way, accentuating the origins of culture and the authenticity of primitive societies. The positive usage of the primitive with regard to Montenegro reached its peak with anthropologist Gerhard Gesemann's Der montenegrinische Mensch, published in Prague in 1934. His study of patriarchy was a sophisticated melding of current vogues for reborn Sparta, the Darwinian vitality of "agon" cultures and the communion between a people's soul and the soil where it dwells that produces its respective anthropological race. ${ }^{15}$ A primitive race lives by heroic moral codes, safeguarding purity, continuity, and the genetic selection of the physically and morally strongest-notions familiar from Friedrich Nietzsche's Beyond Good and Evil.

12 Ibid., 19.

13 Ibid., 4: “[...], daß diese ungeheure wirtschaftliche Rückständigkeit im engsten Zusammenhang mit dem sozialen und kulturellen Primitivismus des Volkes steht." The use of the term "primitivism" is insofar surprising as the term was used in a positive sense within ethnology for a long time.

14 See Schön, Montenegrinische Kriegführung, 21.

15 Gesemann, Der montenegrinische Mensch, 63: "'Blut' ist hier eine zugleich naturhafte und moralische Kraft. Züchtung der Rasse in diesem Doppelsinne-Rasse ist aber nach gentiler Auffassung, nicht nur 'was man hat,' sondern auch 'was man ist'-ist dem Gentiliker keineswegs eine 'naturwissenschaftliche' Angelegenheit, die den Menschen in seiner geistigen Würde herabsetzt und dem Tiere gleichstellt, im Gegenteil: sich gehen zu lassen, den Instinkten des Wohllebens, des Sentiments, der Sinnlichkeit, der Liebe zu folgen, das ist animalisch, das ist 'Natur' im Sinne von Nicht-Kultur, denn Kultur heißt Ueberwindung der Natur mit ihren eigenen Waffen." 
Gesemann's theories took up a strain that recurred in National Socialist ideology, ${ }^{16}$ but his characterization of the Montenegrin has other precursors as well. In the Austrian officer Josef Schön's treatise, for example, one can observe a similar oscillation between revulsion and respect or even admiration for Montenegrin cruelty, irrationality, and disregard for material possessions, in particular real property. These shortcomings can also be read as discipline, courage, and the indomitable longing for freedom. Schön and his sources do not call their Montenegrin society "primitive," despite its characteristics' convergence with those outlined by Gesemann. The primitivism they have in mind can be defined by the blind spots of colonialism in dealing with native cultures that disregard its values and offer differing practices and techniques. Native habits that do not fit into to a colonizer's ideological system are not even grasped as following an unknown logic, but as being either the ideology's opposite, a deviant form of it, or entirely bereft of reason.

In an 1874 treatise, for example, the Austro-Hungarian officer August Terstyánszky calls the Montenegrin style of combat "inversion." Feigning retreat, they provoke pursuit to get the chance to break the enemy's train, effortlessly ambushing columns from behind rocks while blending seamlessly with the landscape. ${ }^{17}$ Schön avers that the Montenegrins "jump from cover to cover like swarms of locusts"18 in desert regions lacking even a bush to hide behind. For Schön, Montenegrin fighters were a natural phenomenon, more reminiscent of a plague than of the human cultural practice of making war. The partisan's renaturalization and the resulting difficulty of distinguishing him from the geological space he inhabits in the mind of the observer abnegates the realm of reason, treating the enemy unit as a natural disaster against which any military endeavor is bound to fail. On such a view, the Montenegrin warrior is neither accustomed, nor prone, to fight strategically. He seeks, instead, the manly duel between equally matched opponents, oblivious of the danger

16 Cf. Klaas-Hinrich Ehlers, "Prager Deutsche im Prager Zirkel: Ein Überblick," http://www.viadrian.euv-frankfurt-o.de/ sw1www/PublikationenEhlers/ PragerDeutsche.rtf (accessed in November 2007), and in Prager Strukturalismus: Methodologische Grundlagen, ed. Mared Nekula (Heidelberg: Winter, 2003), 70. See also Christian Töchterle, "Wir und die Dinarier-Der europäische Südosten in den rassentheoretischen Abhandlungen vor und im Dritten Reich," in Südostforschung im Schatten des Dritten Reichs, eds. Mathias Beer and Gerhard Seewann (Munich: Oldenbourg, 2004), 170-174, on Gesemann's combination of race, characterology, and physical anthropology.

17 August Terstyánszky, kgl. ung. Honved-Oberst, Das strategische Verhältniß des serbisch-bosnischen und bulgarischen Kriegsschauplatzes gegenüber dem Österreichisch-ungarischen Staate, nach den besten Quellen bearbeitet (Vienna: Verlag der Buchhandlung für Militär-Literatur Karl Prochaska, 1874).

18 Schön, Montenegrinische Kriegführung, 21. 
or even eagerly prepared to lay down his life for his motherland. At the same time, he attacks from ambush, from nowhere and everywhere, and any ostensible strategy-for example, the retreat mentioned above-is a ruse. That the heroic Montenegrin soldier could hardly be distinguished from a marauding bandit points up a latent gap between military and chivalric ideals. The affinity between his style of combat and his proverbial sheep rustling ${ }^{19}$ would not be denied by the "typical" Montenegrin, and his moral self-assessment would conflict with the Austrian's: In the right context, ambush and robbery are honorable acts. ${ }^{20}$

According to many reports, in Montenegro, "the soldier" or "the warrior" is everyman. Although there is a regular army, the task of warding off intruders is shared by all, even women. Following literary scholar Eva Horn, ${ }^{21}$ Montenegro's "soldiers" must be viewed as the equivalent of partisan guerrillas elsewhere-a scheme that subverts the political and social rules of war, whose laws, limits, and structures it constantly transgresses. War requires rules and explicit professionalization, that is, the potential to recognize combatants by their uniforms and weaponry as visible signs of military rule; in Montenegro, where, at the first sign of danger, shepherds leave their herds and businessmen close their shops, mustering brothers, sons, uncles, fathers, and grandfathers, the rules of war are abandoned, countering war's social order with disorder and the interpenetration of the civilian and military orders. In short, one finds in Montenegro the four criteria proposed in Carl Schmitt's Theory of Partisanship (1963): First, Montenegrin soldiers break the rules of war and are thus not legitimate soldiers, signifying their irregularity. Second, a tendency toward dispersed skirmishes and surprise attacks points to their increased mobility. Third, their disregard for danger and the loss of possessions indicates the intensity of the partisan ethos. Finally, the telluric character ${ }^{22}$ of the largely defensive fighting of Montenegrins is generally attested.

Horn $^{23}$ reads Carl Schmitt via Gilles Deleuze and Felix Guattari, whose "nomads"- defined as opposition to the apparatus of war-share qualities with Schmitt's partisans. This is no accident: Regardless of discipline, an alignment takes place between notions of primitive/native cultures and telluric character traits to random logic, warriordom, calculated mobility, the intensity of honor

19 See Gesemann, Der montenegrinische Mensch, 66-68.

20 Ibid.

21 Eva Horn, "Partisan, Siedler, Asylant: Zur politischen Anthropologie des Grenzgängers," Ästhetik und Kommunikation, September 1998, 39-46.

22 Telluric describes a people culturally and emotionally bound to its territory. The telluric character leads to a strong territorial community and its defense against invasions and foreign influence, since identity, culture, and territory are seen as interdependent.

23 Horn, "Partisan, Siedler, Asylant." 
and combat, and partisanship as an ethos and, thus, a culture in its own right. The vector that can be drawn is likewise transdisciplinary, since its movement, like nomadic movement itself, neglects the limits of disciplines and even of thought, combining ethnography, anthropology, mathematics, economics, cultural studies, the social sciences, and politics. Meditation on partisan warfare and nomadism contaminates ordered thought and reason with its own extravagant momentum. The topic of decentralization, for example, catapults Schön's reasoning to its own limits: The decentralized structure of the country will disqualify any attempt to conquer it. Thus, Schön repeatedly claims that Montenegro has no capital in the strict sense.

The occupation of Cetinje would do harm only to its inhabitants, yet would not considerably affect the country's defense. The whole situation is patriarchal in a simple way; organization, government, military support are not in the least dependent on a structured and complex bureaucracy as in larger states. It makes no difference whether Cetinje or some other town functions as the centre of command organising the resistance. ${ }^{24}$

\section{Ethno-/geo/graphy and Anthropogeography}

Schön and others explain the Montenegrins' constant state of alert, their many incursions into neighboring countries, such as Albania and Dalmatia (then part of Austria-Hungary), and their success in defending their territory against conventional armies by reference to ethnogeography. They argue that a country's geography forms its inhabitants; the development and adaptation of human culture takes place within a certain range of possibilities offered by the environment, while others are excluded. In the case of Montenegro, the idiosyncratic refusal to establish communications and the choice to perpetuate a premodern civilization is closely connected to the mountainous landscape as well as to Montenegro's being a "political island" 25 whose every border adjoins

24 Schön, Montenegrinische Kriegführung, 28: "Auch ein geographisches Operationsobjekt-wie es anderwärts etwa die Hauptstadt ist—fand sich für ein Invasionskorps nicht."

25 See Friedrich Ratzel, Politische Geographie, 3rd ed., revised by Eugen Oberhummer (Munich: Oldenbourg, 1923), 237: "Solche ganz umschlossene Gebiete könnte man als politische Inseln bezeichnen. Staaten von auch nur mäßiger Größe haben sich solcher Umarmungen mit aller Macht erwehrt oder sind darin untergegangen. [...] Es ist aber sehr interessant, zu sehen, daß selbst die kleinsten sich auf den Grenzen zweier großen entwickelten oder erhielten, wie Andorra zwischen Frankreich und Spanien, Liechtenstein zwischen Österreich und der Schweiz, Montenegro zwischen Österreich und der Türkei." 
an Empire (Austria-Hungary, the Ottoman Empire) or at least a larger country (the Kingdom of Serbia). An insular "dwarf state" must keep its weak borders inviolate while its own population crosses them at will, whether on business, conquest, or raiding forays.

Montenegrin society is analyzed by the military either as occupying a special ecological niche dictated by the environment or as a primitive society bearing traits of nomadism. The harsh geography at once provides "natural" borders and makes raids on neighboring countries inevitable, so that the seeming paradox of a nomadic-telluric culture can be traced to political geography: Geographic and political borders leave their impact simultaneously, and political borders are not arbitrary. Whenever they are drawn without regard for geography, turmoil arises. When we consider Deleuze and Guattari's conception of nomadism, the Montenegrin invasions of Albania-its repeated conquests of Scutari and subsequent retreats-represent not only the geography of crisis caused by unnatural borders, but also signify the special border-space of nomadism. Such attacks have a destabilizing effect upon coercive social systems, since uncertainty with regard to the duration of the occupation and its aims, if not territorial annexation, has a disorienting and disordering effect.

An equation of nomadic conquests with mere raids, a clear indicator for nomadic society's premodern status, was formulated by the influential German geographer Friedrich Ratzel in his Political Geography (1897), where nomads occupy the lowest rung of political culture. While Deleuze and Guattari share basically the same geographical parameters in their definition of nomadism, several important aspects differ from Ratzel's definition: They refuse to place nomads within a social hierarchy of status or value; nomadism is primarily a spatial paradigm; and, most importantly, the space that nomadism creates becomes a principle in and of itself. The noncapital Cetinje described by Schön and the country's shifting lines of communication are both symptomatic of the motile structure of a social geography in which strategic locations and property play negligible roles. It becomes a principle of human geography per se-the Other of a modern, highly structured machinery of war. Viewed in this way, nomadism is deessentialized, no longer bound to particular peoples or cultures, but may be observed in any society.

Austrian travelers and military did not use the term nomad, though they clearly-if with mixed feelings-outlined a seminomadic society that functioned as an Other for their own culture. One is struck by their admiration for the nomadic warriors of Montenegro as well as for the seamless space the partisans create by their peculiar way of fighting. In remarks on Montenegrins' habit of torching their homes when the enemy closes in ${ }^{26}$ it is evident that a disregard for material possessions occasions not only bafflement, but also respect.

26 See Schön, Montenegrinische Kriegführung, 27-28. 


\section{The Question of Borders in the Wake of the Congress of Berlin}

The 1878 Congress of Berlin granted Montenegro some measure of autonomy, and negotiations as to its territory could begin. As agreed at the Conference, a Delimitation Committee was established to redraw the borders. However, unexpected diplomatic impasses, as well as serious errors in the Austrian maps that were to serve as the basis for its work, doomed the Committee to delay and inactivity.

It was no surprise that the Ottoman Empire was less than delighted about ceding Albanian territory to Montenegro, and that it tried to hinder the proceedings. But the inaccuracy of the Austrian surveys came as a shock. Quite a few Austrian officials had traveled in the region and were proud of having provided details or corrected earlier mistakes. Given its strong imperial interest-which, as Ratzel remarked, came "naturally," since this "dark part" of Europe lay at its doorstep, while Germany's central location among civilized neighbors ${ }^{27}$ pushed its territorial ambitions overseas-Austria had been expected to work more conscientiously. But the maps' troubles did not originate with their representation of coastlines, rivers, and other natural phenomena, which were more or less correct, nor yet in the placement of cities and towns, but rather in the pitfalls of mapping itself.

Jacob Fischler discusses the example of the island of Gorica-Topal in Lake Scutari, which had been tentatively assigned to Montenegro. ${ }^{28}$ The island could not be found. An island roughly corresponding to the location on the map had a different name, while one bearing a similar name was situated at quite a distance and was thus of little use for drawing a straight border. The case of the stray island, though it seems ludicrous, raises three important points.

First, it is not the map itself, but rather the split process of signification that causes uncertainties and polysemy. A name is not merely a name, liable to willful change, despite the arbitrary nature of the sign. In a name, especially that of a significant location, entire stories are conveyed-narratives meaningful to the members of a community. Yet, the map does not consist of linguistic signs alone: There are also pictorial and diagrammatic signs, again connected in an arbitrary way. The misplacement of a single name in such a fragile system of interdependencies among pictorial, linguistic, and topological signs, which are hardly congruent in the first place, destroys its balance. While names embed narratives to which graphic elements alone are unable to refer, the pictorial or diagrammatic aspect of late nineteenth-century military maps, such as the Austrian map of the Balkans, is

27 Ratzel, Politische Geographie, 233.

28 Jacob Fischler, Die Grenzdeliminitierung Montenegros nach dem Berliner Kongresse vom Aug. 1878 bis Okt. 1887 (Vienna: self-published, 1925), 27. 
more an instrument of discipline than one of depiction. With elementary graphic symbols, the point and the line, it marks spaces of possession and belonging to be made accessible or inaccessible. Narratives, though they can be located, do not serve to mark possessions. Through their diachronic aspect, narratives partialize spaces, while a diagram totalizes them. The selection of a single name is already a distortion of those narratives, much as a diagram distorts the visual.

Second, the establishment of a border is a symbolic act that impacts not only the map's representative system, but, to a much greater degree, the people living in the border region-in a physical sense. They are expected to respect the border and its rules. To follow their usual ways of life, to walk their everyday routes to markets or houses of worship, or to pay visits to their families can become acts of trespassing.

Third, and closely connected to the second point, borders must be visible. In the nineteenth and early twentieth century, it was held that borders should follow so-called "natural" delimitations-ecological or geographic markers, such as rivers, coastlines, or the edges of mountain or desert regions. But ethnic, or in this case tribal, distribution was considered equally relevant. Ethnographic knowledge taken from diverse sources was applied to the creation of maps, with the aim of formalizing the existing dispersion of tribes. The Congress and the Delimitation Committee freely ascribed loyalties and values to the inhabitants of the newly established border regions. For instance, sections of Albanian tribal territory (Gusinje-Plava) in which most inhabitants were orthodox Christian Slavs were designated Montenegrin. ${ }^{29}$ But "ethnographic" knowledge of shared ethnic roots and faiths failed in its implementation; their supposed loyalties meant little to the population.

The attempt to satisfy Montenegro's territorial claims by ceding a northerly section of Albania to it led to even more serious problems. Albanian tribal chieftains (of the Hotti, Dinosch, Gruda, Touzi, Clementi, Selca, Vukel, Nikshi, and Lumba) pleaded with the Great Powers to prevent the loss of their status as Ottoman vassals. Their petition was sent to Kirby Green on May 2, 1880:

We have once before protested against the violation of the Treaty of Berlin, by which [...] a part of our territory had been awarded [to Montenegro]. [...] We declared to you that we would never accept the notoriously unjust, oppressive, and ill-constituted Government of Montenegro. [...] We repeat our former prayer that our incorporation with that unjust Government be prevented, and that, in conformity with the Treaty of Berlin, we be allowed to remain under the jurisdiction of our former and well-beloved Master the Sultan. ${ }^{30}$

29 See enclosure in No. 237, "Memorandum on the Montenegrin-Albanian Frontier Question (June 1880)," in Montenegro: Political and Ethnic Boundaries, 1840-1920, ed. Beitullah Destani (London: Archive Editions, 2001). 
The ongoing drawing and redrawing of the Montenegrin-Albanian frontier had unexpected side effects. The northern Albanian tribes shifted their loyalties from the Montenegrin tribes to the Great Powers and back again, according to momentary circumstances, in hopes of gaining additional autonomy. A few communities were indeed of mixed tribal/ethnic Albanian-Montenegrin identity, but even their representatives did not appreciate plans to surrender territory to Montenegro. Their resistance was encouraged by contemporary discourse that prompted them to discover their identity as Albanians. As they consolidated their sudden national integrity, it became impossible to approach Montenegro in any way, culturally or politically. Borders formerly permeable were made coercive. ${ }^{31}$

The ethnographic knowledge that Austrian travelers had collected during fifty years of study, with all their sensitivity to regional wants and loyalties, became useless and even counterproductive as the social space shifted from tribal bonds to national belonging and a history and culture shared with Turkey. Modernity's preference for nation-building and autonomous states had shattered the "darkness" of Albania long before Austria-Hungary came along. Its efforts to take local bonds and boundaries into consideration in the installation of political borders were quickly invalidated by fresh developments.

\section{Ethnographic Knowledge and Its Limits}

The ethnographic findings of Austrian, German, Czech, Hungarian, and other travelers were, in large part, based not on methodical collection, comparison, and evaluation of its subjects in any scientific or disciplinary sense, but on accounts by earlier travelers, extrapolation from common knowledge, secondhand oral narratives, the perusal of fiction, and short visits. Austria's "natural interest" in the Balkans, as Ratzel had called it, had always extended to ethnographic or rather anthropogeographical research. As had been the case with the redrawing of the Montenegrin-Albanian border at the Congress of Berlin, expectations were sometimes high: Ethnographic sophistication would enable Austria to extend its influence, preparing the region for diplomacy or for "civilizing" warfare.

Whatever the source, the ethnographic assessment of Montenegro's tribes, society, customs, national character, and mental or emotional disposition remained controversial. Its characterizations of the Balkan peoples ranged from "uncivilized" to "Homeric," from atavistic throwback to optimum raw

31 Allen Buchanan and Margaret Moore, "Introduction," in States, Nations, and Boundaries: The Ethics of Making Boundaries, eds. idem (New York: Cambridge University Press, 2003), 2. 
material for modernization. In analyses conducted from an imperialist vantage point and focused on developing strong centers, industrialized production and trade, Montenegro was accorded scant prospects of modernizing itself-geographically and culturally isolated from the neighboring countries as it is, as Ratzel puts it. ${ }^{32}$ Zenker, too, begins with geography: With regard to Montenegro's isolation, he, for once, does not compare it to Switzerland or Sparta, but to Tibet. Trapped by a culture that renders modernization impossible, the country's mineral resources and potential agriculture and industry are treated as subject to Austria's colonial whims. An Austro-Hungarian protectorate in Montenegro could solve its cultural and political problems simultaneously: Agriculture would replace the seminomadic lifestyle and discourage further raiding, ${ }^{33}$ with the hitherto fallow fertile soil around Podgorica gained in the Treaty of Berlin playing a pivotal role. ${ }^{34}$

Yet, neither ethnographic knowledge of its decentralized tribal structures, nor the superior "civilizing" techniques of the Austrian military proved helpful in the brief years of the Austrian occupation (1916-1918), despite the fact that the military government in Cetinje was led by officers who had both collected ethnographic data and fought against the Montenegrins. There are intimate connections between military and ethnographic knowledge, and civilization and war. The latter link is recapitulated by the German ethnographer Hugo Grothe, who traveled through Montenegro and Albania in 1912: "The war in the Balkans no doubt promotes civilization there and opens up great potentials for capital and investment, for technology, and for the individual pioneer who investigates the cultures and economic situation of these regions." 35 Nevertheless, all the optimism about "civilizing warfare," which, to a certain extent, relies on ethnographic knowledge - the civilizing mission of the military administration transforms the tribal into a "civil" society, implementing economic and civilizing techniques and administrative and executive institutions-was disappointed, as was the hope of quick transformation and progress after the victory. Arguing that sharecropping was "manly" did not turn herdsmen into farmers; instead, the supply of staple foods failed-let alone the transfer of agriculture as a technique of civilization. No sophistication about family ties could prepare the army for local subsystems of supply redistribution, which cut off the most needy Montenegrins. Swords were not turned into ploughshares, but instead were used in impromptu rebellions.

32 Ratzel, Politische Geographie, 227.

33 Ibid., 52-53.

34 For Austria-Hungary's mission in the Balkans, see Konstantinović, Deutsche Reisebeschreibungen, 119.

35 Hugo Grothe, Durch Albanien und Montenegro (Munich: Mörike, 1913), 8. 
Still, ethnographic knowledge was not dismissed as valueless. Military administrators were encouraged to keep journals ${ }^{36}$ preformatted into categories, including "social life," "habits and holidays," and "economic development." Especially interesting are the diaries kept by officers responsible for the judicial system. Their entries reliably mirror Austrian law, moral codes, and cultural values. Some entries evince the moral code's state of volatility: Complaints about parallel economies among members of families and tribes are frequent. Attempts to prove Montenegrins guilty of using neighbors' names to divert food supplies for their own families were, however, futile. The Austrian military's awareness of kinship-motivated fraud collided with their system of humanitarian aid. The impossibility of prosecuting the swindlers compounded the image of tribalism as socially primitive. Apart from such cases, the records cite violations of prohibitions on possessing firearms as the most common grounds for conviction, with pan-Serbian conspiracies also causing plentiful trouble. As one diary from Plevjle records in a summary dated February 10-28, 1917 , women played crucial roles in such conspiracies. In that particular case, prosecution was ineffective, because communication between the Montenegrin and Serbian conspirators was so much faster and more efficient than the official bureaucratic communications of the Austrian officials.

Where Austrian authority was met with violent resistance, the occupiers appropriated "tribal" law to make entire clans responsible for a single offence. For example, after Radomir Vešović escaped from arrest by killing an Austrian constable, half the inhabitants of his hometown of Kolašin were executed or jailed. Another case is documented in the K.u.K. Kundmachung Nr. 3061, An das k.u.k. Kreiskommando Nikšić, Feldpost 257 am 20.10.1918: The Austrian administration of Montenegro had ended. To guarantee a secure retreat from Nikšić, it was recommended that the troops take hostages-preferably immediate family; if they were unavailable, then other relatives or friends. ${ }^{37}$ In such cases, a cultural transfer took place from the tribal/primitive to the civilized. No satisfying attempt was made to justify the condemnation of half a village for one man's crime in legal terms; eager to demonstrate their mastery of the language of "blood," the Austrian administration simply adopted tribal norms of honor and kinship. Montenegro, it is suggested, with its brute men clinging to weapons, liberty, and interclan loyalties, offered them no latitude for negotiation. Austrian officers' "Balkanization" occurred through their co-optation or recuperation and re-"naturalizing" of tribal language, an effect familiar

36 These diaries (including also the aforementioned troubles with interclan supply) are to be found in documents from the Armeeoberkommando Cetinje 1917 and 1918 in the Viennese War Archive.

37 Roberts speaks of "considerable brutality" against civilian populations. Roberts, Realm of the Black Mountain, 318. 
from colonialism. Ethnographic knowledge played no further role in the occupation. If there ever had been widespread faith in its utility, Austrians quickly lost it.

The precise position of ethnographic knowledge between prejudice and phantasm can be difficult to specify, especially in its dealings with a group that embodied coherent and contradictory narratives-the warrior nomad's patriarchal purity, the living relic of ancient Sparta, the devious, emotionally unstable barbarian. The Austrians' civilizing mission, having subrogated that knowledge to a grand narrative of progress and reason, spoke two languages simultaneously: An abundance of official bulletins ${ }^{38}$ focused on positive aspects, trying in sundry ways to make industrious, pious, responsible masculinity more palatable to the Montenegrins. Failure was preprogramed, as ethnographic knowledge, prejudice, and personal experience inevitably reinforced one another. In the end, common knowledge simply reproduced itself, reifying Montenegro's image as a nation of petty warlords.

38 Published in Cetinjer Zeitung (1916-1918). 
